\title{
Drought reconstruction based on grape harvest dates for the Czech Lands, 1499-2012
}

\author{
M. Možný ${ }^{1}$, R. Brázdil ${ }^{2,3}$, P. Dobrovolný ${ }^{2,3}$, M. Trnka ${ }^{2,6}$, V. Potopová ${ }^{4}$ P. Hlavinka ${ }^{6,2}$, \\ L. Bartošová ${ }^{6,2}$, P. Zahradníček ${ }^{2,5}$, P. Štěpánek ${ }^{2,5}$, Z. Žalud ${ }^{6,2}$ \\ ${ }^{1}$ Czech Hydrometeorological Institute, Doksany Observatory, 41182 Doksany, Czech Republic \\ ${ }^{2}$ Global Change Research Institute AS CR, Bělidla 986/4a, 60300 Brno, Czech Republic \\ ${ }^{3}$ Institute of Geography, Masaryk University, Kotlářská 2, 61137 Brno, Czech Republic \\ ${ }^{4}$ Faculty of Agrobiology, Food and Natural Resources, Czech University of Life Sciences Prague, Kamýcká 129, \\ 16521 Prague 6, Czech Republic \\ ${ }^{5}$ Czech Hydrometeorological Institute, Regional Office Brno, Kroftova 43, 61667 Brno, Czech Republic \\ ${ }^{6}$ Faculty of Agronomy, Mendel University in Brno, Zemědělská 1, 61300 Brno, Czech Republic
}

\begin{abstract}
The timing of maturity of grapes depends on the weather conditions during the growing season. This study relies on the dependence of harvest dates on the air temperature and dry/wet conditions. Recorded observations show that increases in air temperature and dryness are associated with earlier grape harvests. Documentary data of grape harvests from the Bohemian wine-growing region (mainly northwest of Prague) were combined with mean Standardized Precipitation Evapotranspiration Index (SPEI) series starting in 1841 and ordinary least square regression with subsequent scaling to reconstruct the mean SPEI values for this area for April to August from 1499 to 2012. The reconstructed SPEI series explains $75 \%$ of the drought variability since 1841. All dry years that were detected by the reconstructed April-August SPEI values correlate well with years of excellent and good red wine of vintage quality for 1499-1840. A comparison of the reconstructed series with other SPEI reconstructions from the Czech Lands (the recent Czech Republic) based on documentary and instrumental data shows good agreement. The results demonstrate that grape harvest series may be used as a proxy for drought reconstruction in the central European region.
\end{abstract}

KEY WORDS: Climate reconstruction · Drought - Grape harvest dates · SPEI · Bohemian wine-growing region

\section{INTRODUCTION}

Documentary data are important proxies that can be used to study climate before the instrumental period (Brázdil et al. 2005, 2010, Jones et al. 2005). Grape harvest dates (GHDs) have been successfully used for several temperature reconstructions, mainly for spring/summer temperatures. GHD is mainly influenced by the local temperature during the stages before the bloom and veraison (Chuine et al. 2004, García de Cortázar-Atauri et al. 2010). GHD series have been used for temperature reconstruction over

${ }^{*}$ Corresponding author: m.mozny@seznam.cz large parts of Europe, e.g. in Austria (Strömmer 2003, Maurer et al. 2009), Czech Republic (Možný et al. 2016), France (Le Roy Ladurie \& Baulant 1980, Chuine et al. 2004, Le Roy Ladurie 2005, Menzel 2005, Etien et al. 2008, Garnier et al. 2011), Germany (Glaser \& Hagedorn 1991), Italy (Mariani et al. 2009), Switzerland (Pfister 1981, 1984, Burkhardt \& Hense 1985, Meier et al. 2007) and Hungary (Kiss et al. 2011). An open-access dataset of GHD data from different parts of Europe has been compiled (Daux et al. 2012).

Temperature increases are accompanied by both an earlier onset of phenological phases, such as the

(C) The authors 2016. Open Access under Creative Commons by Attribution Licence. Use, distribution and reproduction are unrestricted. Authors and original publication must be credited. 
beginning of the growing season, and a shortening of the intervals between successive phenological phases (Mozny et al. 2009, Možný et al. 2012). Harvests take place earlier with warmer temperatures and drought, and are delayed by wet conditions; however, enhanced warming from anthropogenic greenhouse gases can generate the high temperatures needed for early harvest without drought (Cook \& Wolkovich 2016).

Advances in maturation dates of approximately 4 to $8 \mathrm{~d}$ per decade have been detected in the major wine-growing regions of Australia, France and Germany (Jones et al. 2005). Other climate variables also likely affect the ripening of grapes. For example, Webb et al. (2012) attributed the earlier ripening in Australian wine regions to temperature increases, soil drying, and/or changes in vineyard management techniques.

Several studies have reflected the growing risk of drought in the Czech Republic (e.g. Brázdil et al. 2009, 2015, 2016a this Special) and Central Europe (Spinoni et al. 2015). For example, a trend towards increased drought occurrence was recorded at most meteorological stations in the Czech Republic during 1961-2012; the greatest decreases in water reserves occurred in May and June (Trnka et al. 2015). Recent studies have also demonstrated the impact of soil moisture on extreme maximum temperatures in Europe (Hirschi et al. 2011, Whan et al. 2015). Occurrences of recent mega-heatwave temperatures have been argued to be due to the combination of soil desiccation and atmospheric heat accumulation (Miralles et al. 2014), and evapotranspiration has been shown to amplify the European summer drought (Teuling et al. 2013).

A drought may be defined as a negative deviation from the climatic water balance in a specific area over a given time interval (Brázdil et al. 2015). While the principal cause of all droughts is a deficit in precipitation over time, higher air temperatures, intense global radiation, lower relative humidity and higher wind speeds increase evapotranspiration and subsequently cause droughts (Allen et al. 1998). The Standardised Precipitation Evapotranspiration Index (SPEI), which was proposed by Vicente-Serrano et al. (2010), is often used to quantify droughts. This index uses the monthly differences between precipitation and potential evapotranspiration. The SPEI has been applied extensively in recent climatological and hydrological studies (e.g. Potop 2011, Heim \& Brewer 2012, Li et al. 2012, Paulo et al. 2012, Potop et al. 2012, Brázdil et al. 2013a, 2015, Beguería et al. 2014, Yu et al. 2014, Potopová et al. 2016).
The main objective of this paper was to use GHDs for the reconstruction of drought series expressed by the SPEI for the Bohemian wine-growing region for 1499-2012, applying standard palaeoclimatological methods. Present results show the relationships between the GHDs and the air temperature, effective rainfall and potential evapotranspiration (including their trends), the long-term reconstructions of SPEI from GHDs and the relationship between the SPEI and vintage quality.

\section{DATA AND METHODS}

\subsection{Study area}

Wine production in the Czech Republic is limited to 2 wine-growing regions: southern Moravia and northwestern Bohemia. Wine-growing has been a tradition in these regions for more than $1000 \mathrm{yr}$. The Bohemian wine-growing region, which is the focus of this paper, is a small historical wine region located near Prague in the northwest part of the country near the Vltava, Ohře and Elbe rivers. Wine grapes are grown on south, southwest and southeast protected slopes at elevations from 170 to $260 \mathrm{~m}$ a.s.l. The vineyards are located around the city of Prague and 7 towns (Kutná Hora, Karlštejn, Mělník, Slaný, Roudnice nad Labem, Litoměřice and Most; Fig. 1a). This region specializes in the cultivation of traditional grape varieties that are suited to the northerly climate and which are particularly frost-resistant and have an early harvest date.

The Czech Republic is characterized by a moderate, humid climate and 4 distinct seasons (Tolasz et al. 2007). The leaf bud burst begins on average between 20 April and 8 May, the beginning of flowering occurs between 5 and 15 June, the end of flowering occurs between 15 and 26 June, and the softening of berries occurs between 1 and 29 August (Hájková et al. 2012). Average annual air temperature in the Bohemian wine-growing region area was $8.7-8.9^{\circ} \mathrm{C}\left(15-15.3^{\circ} \mathrm{C}\right.$ for April-August) and the mean annual precipitation was 480-540 mm (255$280 \mathrm{~mm}$ for April-August) from 1961 to 2000 (Tolasz et al. 2007). The entire Czech wine region falls into Region I according to the standard growing degreedays, representing the climate type 'Cool' according to the Huglin Index and cool climate maturity according to the average growing season temperature index.

The area of investigation is one of the driest regions in the Czech Republic (cf. Brázdil et al. 2015). 


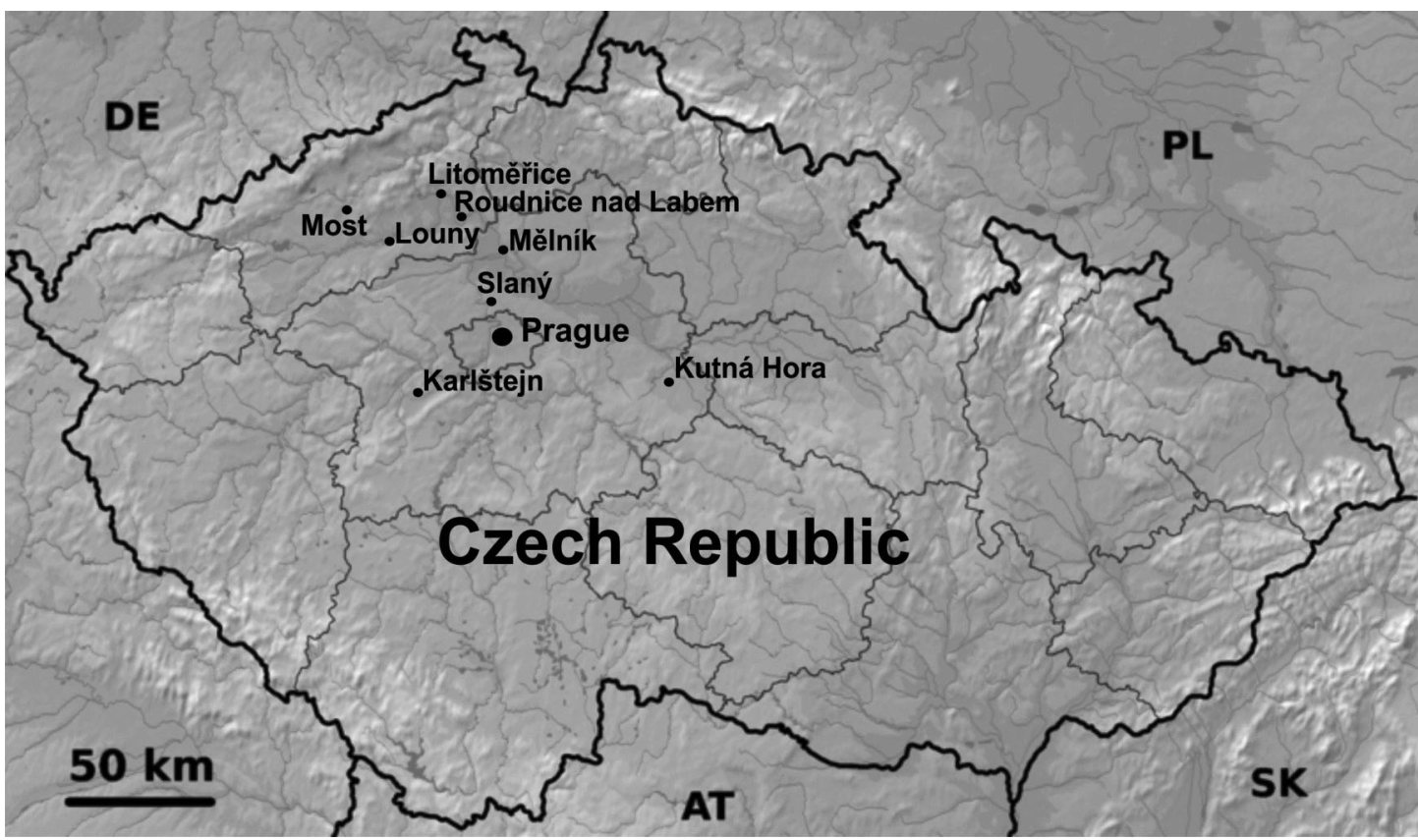

Fig. 1. The Bohemian wine-growing region extends around the places identified on the map

For example, the April-September SPEI data indicate probabilities of the occurrence of dry months greater than $40 \%$ between 1961 and 2012 (Potopová et al. 2016).

\subsection{GHDs and vintage quality data}

GHDs were taken from the PHENODATA database of the Czech Hydrometeorological Institute (CHMI). These data contain systematic phenological observations from several hundred sites in the recent Czech Republic since 1845 (Svitáková et al. 2005). For the period prior to 1845, GHDs were obtained from several documentary sources such as chronicles, town documents, aristocratic documents, ecclesiastical materials, farming calendars, personal diaries, farming records and reports. GHD observations for the Bohemian wine-growing region were compiled for the period from 1499 to 2012 . A total of 5363 harvest dates were collected from 61 sites. While a greater part of the data was related to the systematic observations starting after 1921, fewer data were available before 1700 . There are no temporal gaps in the data; at least one entry was found for each year. The mean GHD series for 1499-2012 used the median values of the data from all of the sites in the corresponding year.

Vintage quality data, which were expressed as the sugar content at ripeness of Vitis vinifera L. cv. Pinot Noir by the Czech-Slovak standards $\left({ }^{\circ} \mathrm{NM}\right)$, were obtained for the period from 1980 to 2015 from the Czech Statistical Office. The data from 1841 to 1980 were obtained from the database of CHMI, data from before 1841 are from the same sources as those described previously for the GHDs. Four classes were used for the vintage quality assessment: 2, excellent; 1 , good; 0 , average; and -1 , poor.

\subsection{Meteorological data}

The meteorological data were taken from the CHMI CLIDATA database. Seven climatological and 33 rain-gauge stations were used to calculate representative mean meteorological time series for the entire Bohemian wine-growing region for the period 1841-2015. The ProClimDB and AnClim software (Štěpánek 2010) was used to homogenize the series using Alexandesson's standard normal homogeneity test, the bivariate test of Maronna and Yohai, the Easterling and Peterson test, and the Vincent method (for additional details, see Štěpánek et al. 2011). We calculated the effective precipitation using the Soil Conservation Service runoff curve-number method (USDA Soil Conservation Service 1972), which uses the daily precipitation, the modeled soil water content in the root zone, the wilting-point water and the field capacity water content (Williams et al. 2012). The Penman-Monteith equation (Allen et al. 1998) was used to estimate the potential evapotranspiration 
for the period from 1961 to 2015. The soil type and available water capacity were taken from the CHMI database, and the SoilClim model (Hlavinka et al. 2011) was used to estimate the soil water saturation.

\subsection{Calculation of SPEI}

Using representative meteorological time series (cf. Section 2.3), SPEI values were calculated for the period from 1841 to 2012. The following steps were applied to calculate the SPEI (Potop et al. 2012, Potopová et al. 2016):

(1) parameterization of the potential evapotranspiration based on the monthly minimum and maximum air temperatures and extra-terrestrial radiation (Hargreaves model; Hargreaves \& Allen 2003);

(2) a simple monthly water balance that was calculated as the difference between the monthly effective precipitation and potential evapotranspiration;

(3) normalization of the climatic water balance into a log-logistic probability distribution to transform the original values to standardized units that are comparable in space and time and to the various SPEI time scales that were utilized in the study area.

\subsection{Reconstruction of SPEI}

The mean GHD series for 1499-2012 was also used as a predictor to reconstruct the SPEI for the Bohemian wine-growing region. A linear regression model (LRM) was used to calibrate the GHDs to the target SPEI values. LRMs are commonly used in paleoclimatology for climate reconstruction (Cook et al. 1994), and this model was recently applied in historical climatology for series of documentary data of (bio)physical series and temperature indices (e.g. Leijonhufvud et al. 2008, 2010, Dobrovolný et al. 2009, 2010, Brázdil et al. 2010). The quality of the LRM calibration was evaluated with the square of Pearson's correlation coefficient $\left(r^{2}\right)$, the standard error of estimate (SE), and the Durbin-Watson test (DW). While $\mathrm{r}^{2}$ and SE evaluate the quality of the regression model, the DW diagnoses the first-order autocorrelation within the regression residuals (von Storch \& Zwiers 1999). DW values between 1.5 and 2.5 are generally acceptable, while those outside this range indicate problems with reconstructing multi-decadal fluctuations.

Verification was based on several measures of reconstruction skill, including $\mathrm{r}^{2}$, reduction of error
(RE) and the coefficient of efficiency (CE, Cook et al. 1994). While $r^{2}$ quantifies the amount of SPEI variability that is explained by the reconstruction, RE indicates whether a reconstruction provides a better estimate of the SPEI variability than simply using the mean value of the target SPEI in the calibration period $\left(\bar{X}_{C}\right)$. RE is calculated as:

$$
\mathrm{RE}=1-\left[\frac{\sum_{i=1}^{n}\left(x_{i}-\hat{x}_{i}\right)^{2}}{\sum_{i=1}^{n}\left(x_{i}-\bar{x}_{C}\right)^{2}}\right]
$$

where $x_{i}$ and $\hat{x}_{i}$ are the target and reconstructed SPEI values for the verification period, i.e. the mean value of target SPEI in the calibration period $\bar{x}_{C}$. CE is similar to RE, but it tests the reconstruction skill against the mean value of the target SPEI in the verification period $\left(\bar{X}_{V}\right)$ :

$$
\mathrm{CE}=1-\left[\frac{\sum_{i=1}^{n}\left(x_{i}-\hat{x}_{i}\right)^{2}}{\sum_{i=1}^{n}\left(x_{i}-\bar{x}_{V}\right)^{2}}\right]
$$

Both RE and CE can have values between 1 and minus infinity. Positive RE and $\mathrm{CE}$ values indicate that the linear regression model has some potential for reconstruction, and the result is better than simply using the mean of a given calibration-verification period as a 'reconstruction'.

\section{RESULTS}

\subsection{GHDs and meteorological variables in 1961-2012}

The beginning of the grape harvest depends on the weather patterns of the preceding months. We found a statistically significant correlation $\left(\mathrm{r}^{2}=0.72, \mathrm{p}<\right.$ 0.001) between the GHDs and the mean AprilAugust temperatures for 1961-2012 (Fig. 2a). Statistically significant relationships were also found between the GHDs and the total potential evapotranspiration for April-August (Fig. 2b; $\mathrm{r}^{2}=0.64$, p < 0.001 ) and the total effective precipitation for AprilAugust (Fig. 2c; $\mathrm{r}^{2}=0.30, \mathrm{p}<0.01$ ).

The GHD changes in the Bohemian wine-growing region are illustrated by the example of the mean GHDs for 1961-2012 (Fig. 3a). A statistically significant trend toward earlier harvests was found during this period $\left(0.33 \mathrm{~d} \mathrm{yr}^{-1} ; \mathrm{r}^{2}=0.30, \mathrm{p}<0.001\right)$. The earliest harvests were recorded in the past $20 \mathrm{yr}$ (1993-2012). The latest harvest dates occurred during 1972-1981, while the earliest dates occurred during 2000-2009. The earliest GHDs were recorded in 2000 (13 September) and 2003 (18 September), and 

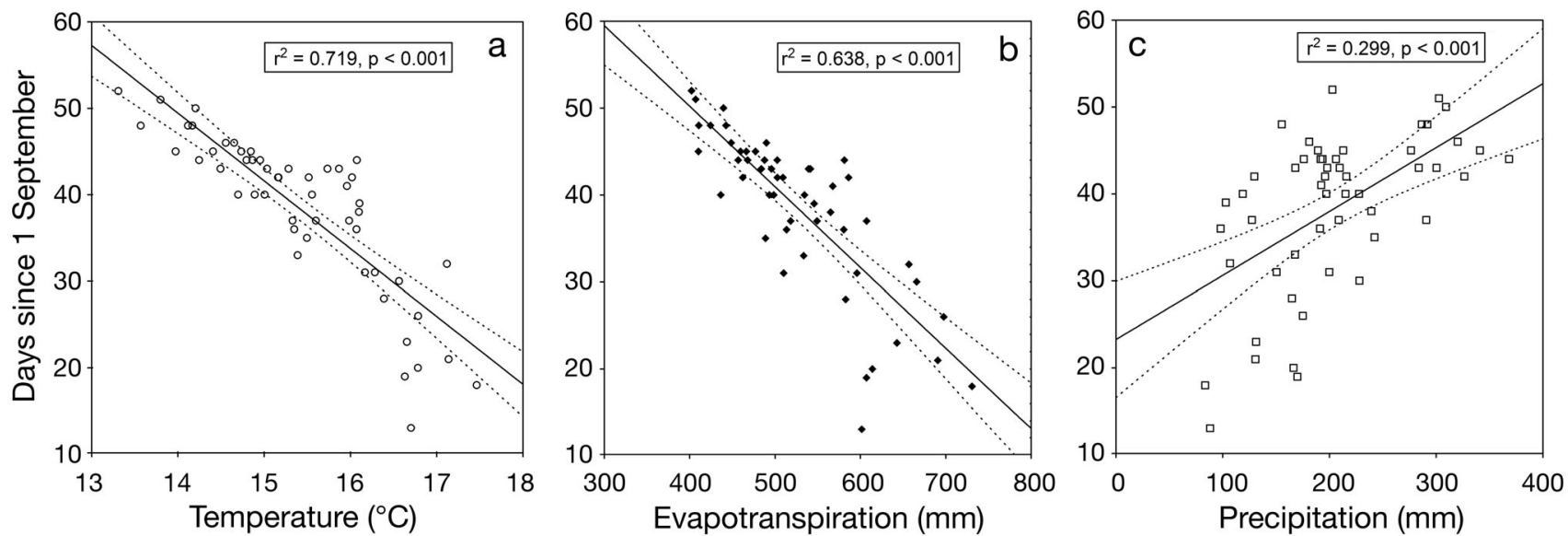

Fig. 2. Relationships between grape harvest dates (days since 1 September) and meteorological variables in the Bohemian wine-growing region for April-August 1961-2012: (a) mean air temperature; (b) total potential evapotranspiration; (c) total effective precipitation. Dotted lines show $95 \%$ confidence level

the latest occurred in 1980 (22 October) and 1965 (21 October).

The climate variability in the Bohemian winegrowing region during 1961-2012 was illustrated by variations of 3 annual series of meteorological variables in the summer half-year (April-August). Statistically significant trends towards higher total potential evapotranspiration and mean temperature were detected $\left(2.7 \mathrm{~mm} \mathrm{yr}^{-1}, \mathrm{r}^{2}=0.57, \mathrm{p}<0.01\right.$ and $0.044^{\circ} \mathrm{C}$ $\mathrm{yr}^{-1}, \mathrm{r}^{2}=0.46, \mathrm{p}<0.01$, respectively; Fig. 3b,c). The highest mean April-August temperature and potential evapotranspiration were recorded in 2003 $\left(17.5^{\circ} \mathrm{C}\right.$ and $731 \mathrm{~mm}$, respectively), while the lowest mean April-August temperature and evapotranspiration occurred in $1980\left(3.3^{\circ} \mathrm{C}\right.$ and $\left.411 \mathrm{~mm}\right)$. The April-August precipitation totals did not show any significant long-term trends (Fig. 3d). Changes in precipitation that coincided with increases in temperature and evapotranspiration did not increase the risk of drought in the vine-growing season. A statisti-
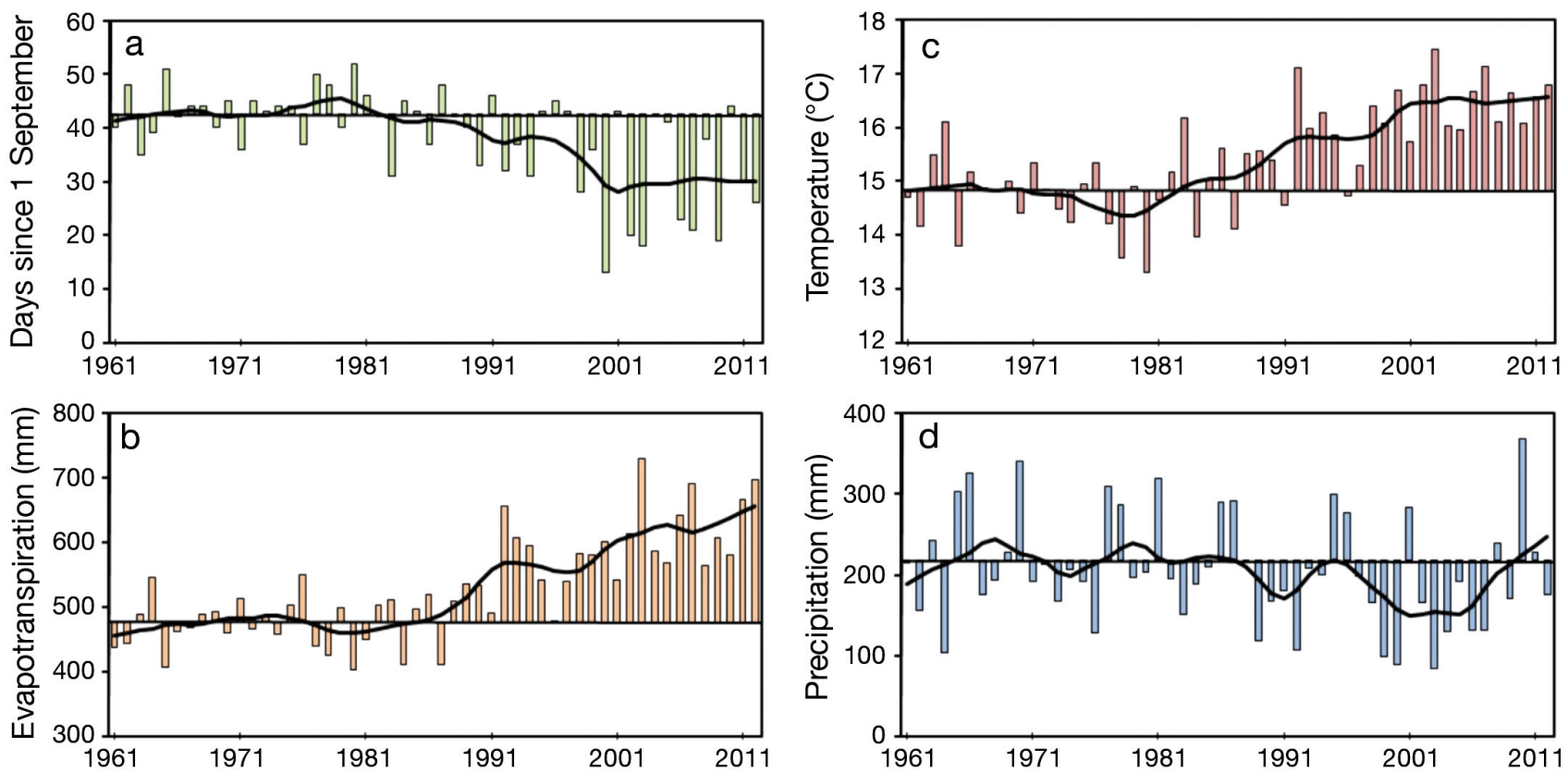

Fig. 3. Fluctuations in grape harvest dates and meteorological variables in the Bohemian wine-growing region for AprilAugust 1961-2012: (a) grape harvest dates (days since 1 September), (b) total potential evapotranspiration, (c) mean air temperature, (d) total effective precipitation. Bars indicate deviations from the 1961-1990 means (horizontal lines). Data are smoothed by a 10 yr Gaussian filter (black line ) 
Table 1. Summary of the calibration and verification statistics that were used for the SPEI reconstruction based on the grape harvest dates in the Bohemian wine-growing region for 2 sub-periods. $r^{2}$ : variance; SE: standard error of estimate; DW: Durbin-Watson test; RMSE: root mean square error; RE: reduction of error; CE: coefficient of efficiency

\begin{tabular}{|c|c|c|c|c|c|c|c|}
\hline \multirow[t]{2}{*}{ Sub-period } & \multicolumn{3}{|c|}{ Calibration statistic } & \multicolumn{4}{|c|}{ - Verification statistic } \\
\hline & $\mathrm{r}^{2}$ & $\mathrm{SE}$ & DW & $\mathrm{r}^{2}$ & RMSE & $\mathrm{RE}$ & $\mathrm{CE}$ \\
\hline Early calibration (1841-1925)/late verification (1926-2010) & 0.70 & 0.48 & 2.20 & 0.77 & 0.48 & 0.79 & 0.76 \\
\hline Early verification (1841-1925)/late calibration (1926-2010) & 0.77 & 0.48 & 2.07 & 0.70 & 0.47 & 0.74 & 0.70 \\
\hline
\end{tabular}

cally significant trend toward earlier grape harvests and statistically significant relationships between the GHDs and the air temperatures, total potential evapotranspiration and total effective precipitation were observed in the study period.

\subsection{SPEI reconstruction based on GHDs}

Overlapping periods of GHDs and calculated SPEI values for 1841-2010 and the linear regression model were used to reconstruct the April-August SPEI for the Bohemian wine-growing region from 1499 to 2012. The calibration and verification were performed twice for early (1841-1925) and late (19262010) sub-periods, and the statistical measures described in Section 2.5 were used to evaluate the reconstruction skill. The entire process was performed for the early calibration and late verification sub-periods, and it was then repeated by switching the calibration and verification sub-periods. The final calibration was performed for the full overlapping period of 1841-2010.

Statistical measures were applied to both sub-periods to confirm the high reconstruction skill of the GHDs (Table 1). The results of the Durbin-Watson test indicate that there were no problems with the autocorrelation in the residuals. The RE and CE values were highly positive and indicated that the GHDs had a high potential for SPEI reconstruction. Fig. 4 shows comparisons of the measured and reconstructed SPEI values for the 2 exercises. The final calibration was performed for the full overlap period; the results indicate that the GHDs explain $75 \%$ of the April-August SPEI variance in the period from 1841 to 2010. A change of $8.9 \mathrm{~d}$ in the GHDs approximately corresponds to a unit change in the AprilAugust SPEI.

The SPEI values that were reconstructed through linear regression were adjusted further to have the same mean and variance over the overlapping period of 1841-2010. Uncertainty estimates were expressed as a $95 \%$ confidence interval, which was defined as 2SE from the regression relationship between the GHDs and the calculated SPEI values within the full calibration period (Fig. 5). These intervals represent what is known as the 'regression error' and evaluate the quality of proxy data for only the calibration period.

The reconstructed series show that several irregular variations of drier and wetter periods occurred between 1499 and 2012. Significantly drier periods (based on unsmoothed data) were found for 15321556 and 1983-2012 (Fig. 5). The early GHDs indicate that the first half of the 16th century was exceptionally dry. Four significantly wetter periods, which occurred in approximately 1650, 1740, 1805 and 1913 and were separated by slightly drier intervals, were detected in the reconstruction. The driest $30 \mathrm{yr}$ periods occurred from 1983 to 2012 (mean SPEI of -0.9), and the wettest occurred from 1900 to 1929 (0.13). The lowest April-August SPEI was recorded in 1540 $(-3.4)$, and the highest was recorded in 1919 (1.9). The fluctuations of the April-August SPEI values show large inter-annual and inter-decadal variabilities and decreasing trends for the 19th century and particularly dramatic decreases since the late 1970s.

\subsection{April-August SPEI and vintage quality}

Vintage quality depends on the weather patterns of the preceding months. We found a statistically significant correlation (Spearman's rho $=-0.79, p<0.01$ ) between the sugar content at ripeness of Vitis vinifera L. cv. Pinot Noir and the calculated AprilSeptember SPEI in the Bohemian wine-growing region in the period from 1980 to 2015 (Fig. 6a). Decreases of the April-September SPEI during previous years were reflected in higher sugar contents of the grapes. Therefore, the SPEI can be considered to be an important factor for the red wine vintage quality in this region. Poor quality vintages correspond to wet patterns, such as in $1980(\mathrm{SPEI}=1.2)$ and 1984 

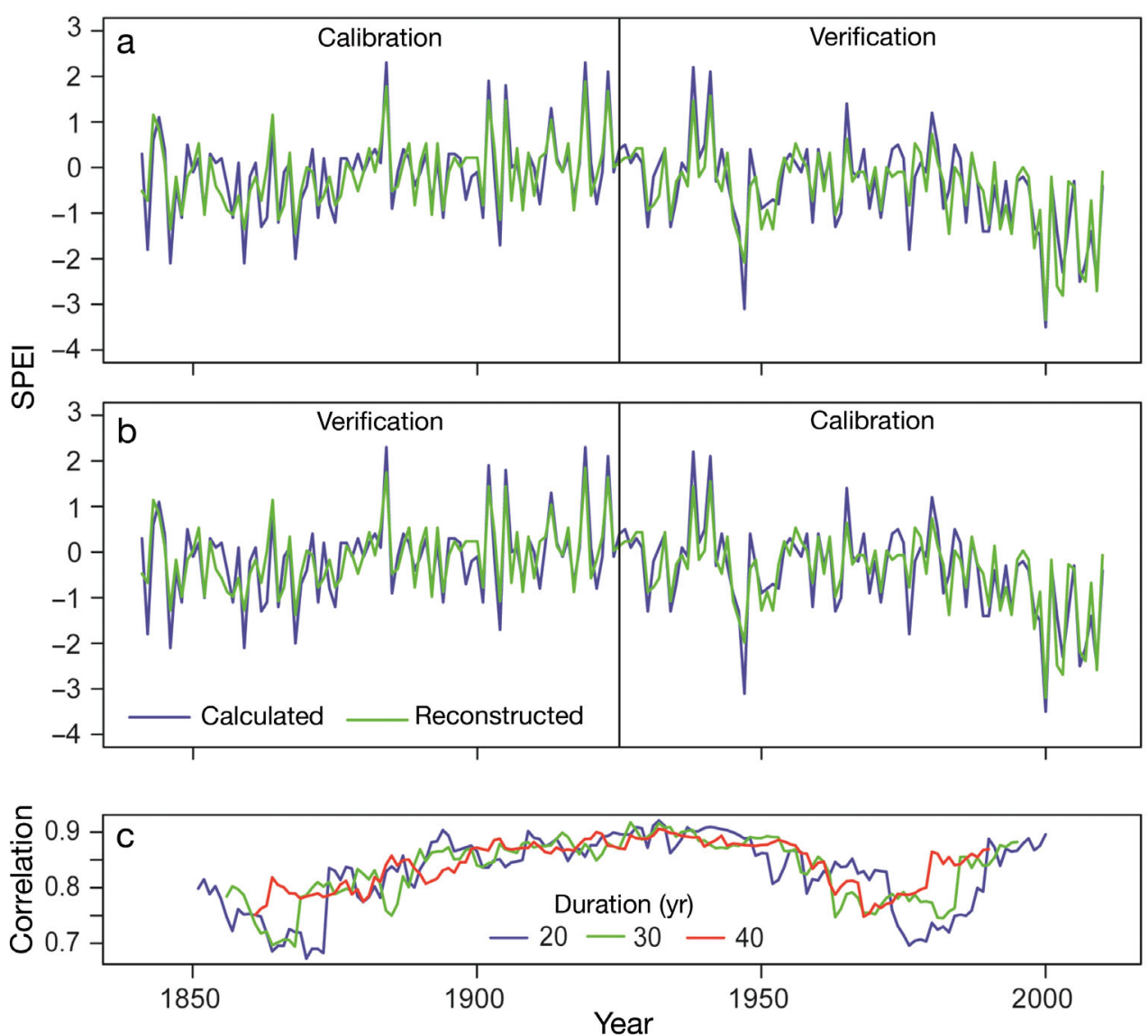

Fig. 4. (a,b) Comparison of the calculated and reconstructed April-August SPEI values for the Bohemian wine-growing region. Reconstructions were performed for (a) early (1841-1925) and (b) late (1926-2010) periods. (c) Running correlations for windows of 3 different durations (20,30 and 40 yr) between the April-August SPEI and the grape harvest dates for 1841-2010

$(\mathrm{SPEI}=0.5)$. In contrast, water deficit stress corresponds to very good or excellent vintages in 2015 $($ SPEI $=-3.7), 2000($ SPEI $=-3.5)$ and $2006($ SPEI $=$ -2.6). A statistically significant trend towards higher sugar content was found during the period from 1980 to $2015\left(0.13^{\circ} \mathrm{NM} \mathrm{yr}^{-1}, \mathrm{r}^{2}=0.91, \mathrm{p}<0.01\right.$; Fig. $\left.6 \mathrm{~b}\right)$. The decade 1981-1990 had the lowest mean sugar content $\left(17.9^{\circ} \mathrm{NM}\right)$, while the highest was recorded from 2006 to $2015\left(21.2^{\circ} \mathrm{NM}\right)$. The highest sugar contents occurred in 2006, 2013 and $2015\left(23^{\circ} \mathrm{NM}\right)$, and the lowest occurred in $1984\left(16.8^{\circ} \mathrm{NM}\right)$ and 1980 $\left(17.2^{\circ} \mathrm{NM}\right)$.

A statistically significant correlation (Kendall's tau $=-0.68, \mathrm{p}<0.01)$ also exists between the reconstructed April-August SPEI and the vintage quality in the Bohemian wine-growing region from 1499 to 1840 (Fig. 6c). As expected, poor vintage quality corresponded to wet periods, and good vintage quality corresponded to dry patterns. The vintage quality series does not show any strong long-term trends during 1499-1840 (Fig. 6d).

\section{DISCUSSION}

\subsection{Relationship between grape harvest dates and meteorological variables}

Although the strong dependence between the GHDs and the air temperature of the growing season is widely accepted and has also been used to test the quality of GHDs (Daux et al. 2012), relationships with other meteorological variables are not commonly used. We found statistically significant correlation coefficients between the GHDs and other meteorological variables (temperature, potential evapotranspiration and precipitation) in the Bohemian winegrowing region in the period from 1961 to 2012. We detected a statistically significant trend towards earlier GHDs, higher total potential evapotranspiration and mean temperatures. A trend towards earlier maturity of wine grapes has been observed in several countries as a result of recent climate change (Webb et al. 2011, Malheiro et al. 2013, Vršič et al. 2014). 


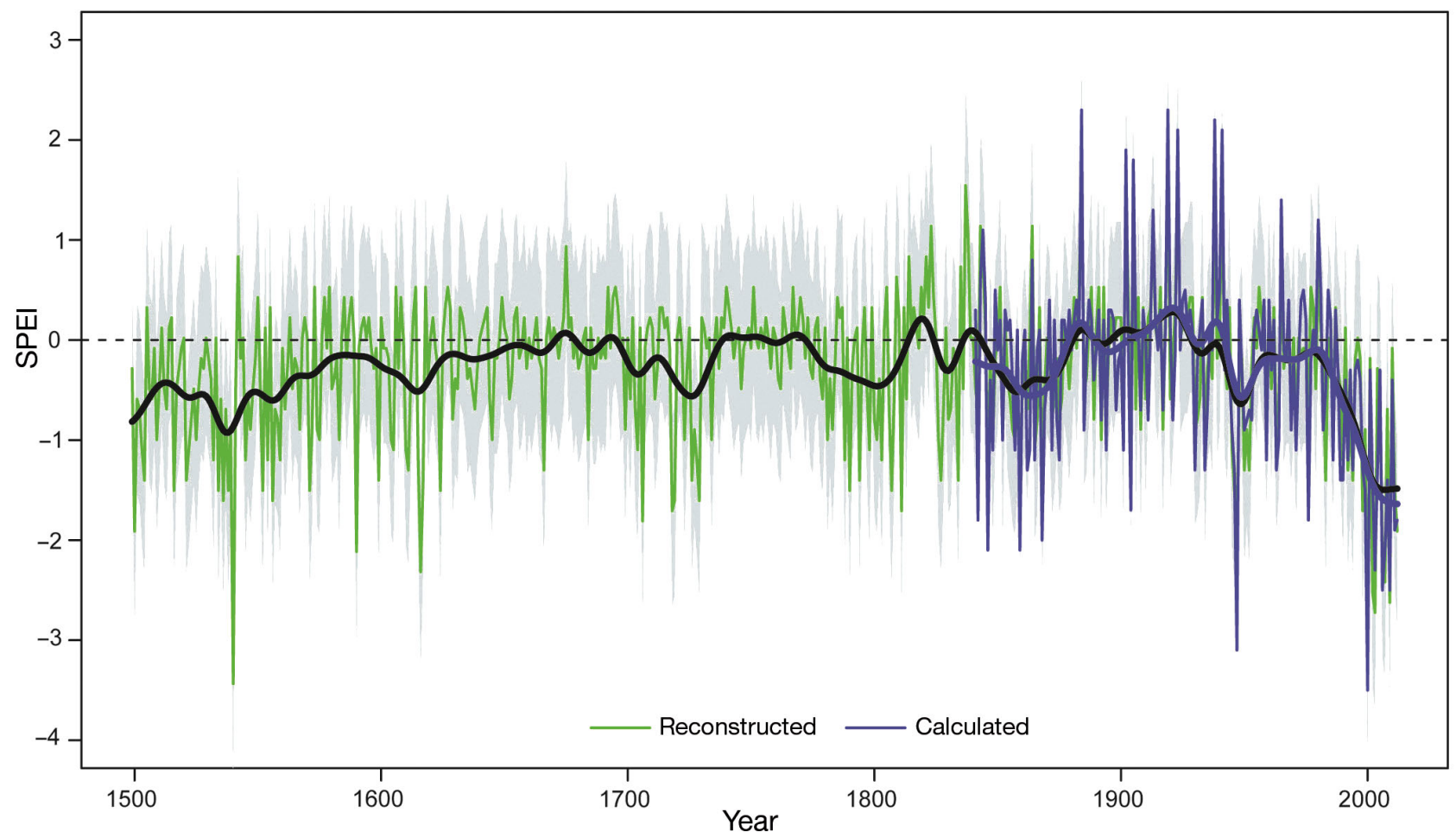

Fig. 5. Reconstructed April-August SPEI for the Bohemian wine-growing region calculated from grape harvest days for 1499-2012 and smoothed by a 30 yr Gaussian filter (black line). The light gray area shows the approximate $95 \%$ confidence interval based on the SE of the estimate. The reconstructed SPEI values are compared with the calculated SPEI values that were smoothed by a 30-year Gaussian filter for 1841-2012

Earlier maturity of wine grapes has been associated with increasing temperature and decreasing soil water content during the growing season in Australia (Webb et al. 2012), but this conclusion was apparently inconsistent with long-term trends of annual rainfall (White 2013). According to Urhausen et al. (2011), who analyzed the relationship between various climatic parameters and phenological stages in viticulture, only temperature-based predictors showed sufficient skill. In contrast, Ramos et al. (2015) found high correlations between the veraison date and temperature variables as well as with precipitation-evapotranspiration data that were recorded during the bloom-veraison period. The interaction of temperature with other meteorological variables must be taken into account; for example, the warm season is often a time of higher solar radiation, lower total rainfall and higher vapor pressure deficits (Sadras et al. 2012). Zahradníček (2009) found high correlations of selected phenophases (e.g. leaf bud burst, beginning and end of flowering, softening of berries) of vines (Vitis vinifera L. cv. Lemberger) with the air temperature and potential evapotranspiration in the Moravian wine-growing region for 1984-2007; the relationship with the total precip- itation was statistically significant. We found statistically significant correlations between the GHD and temperature as well as with precipitation and potential evapotranspiration (calculated by the PenmanMonteith equation) for the period from 1961 to 2015. We used the GHD series to reconstruct the drought index SPEI. The SPEI uses the basic water balance calculation (monthly differences between precipitation and potential evapotranspiration). The inclusion of temperature (the monthly minimum and maximum air temperatures) along with precipitation data allows SPEI to account for the impact of temperature on a drought situation. The output is applicable for all climate regimes, with the results being comparable because they are standardized. With the use of temperature data, SPEI is an ideal index when looking at the impact of climate change in model output under various future scenarios (WMO \& GWP 2016).

Cook \& Wolkovich (2016) investigated the climate controls of GHD from 1600-2007 in France using historical harvest and climate data. Early harvest occured with warmer temperatures $\left(-6 \mathrm{~d}^{\circ} \mathrm{C}^{-1}\right)$ and were delayed by wet conditions $\left(+0.07 \mathrm{~d} \mathrm{~mm}^{-1}\right.$; $+1.68 \mathrm{~d} \mathrm{PDSI}^{-1}$ ) during spring and summer. In recent decades (1981-2007), however, the relationship 

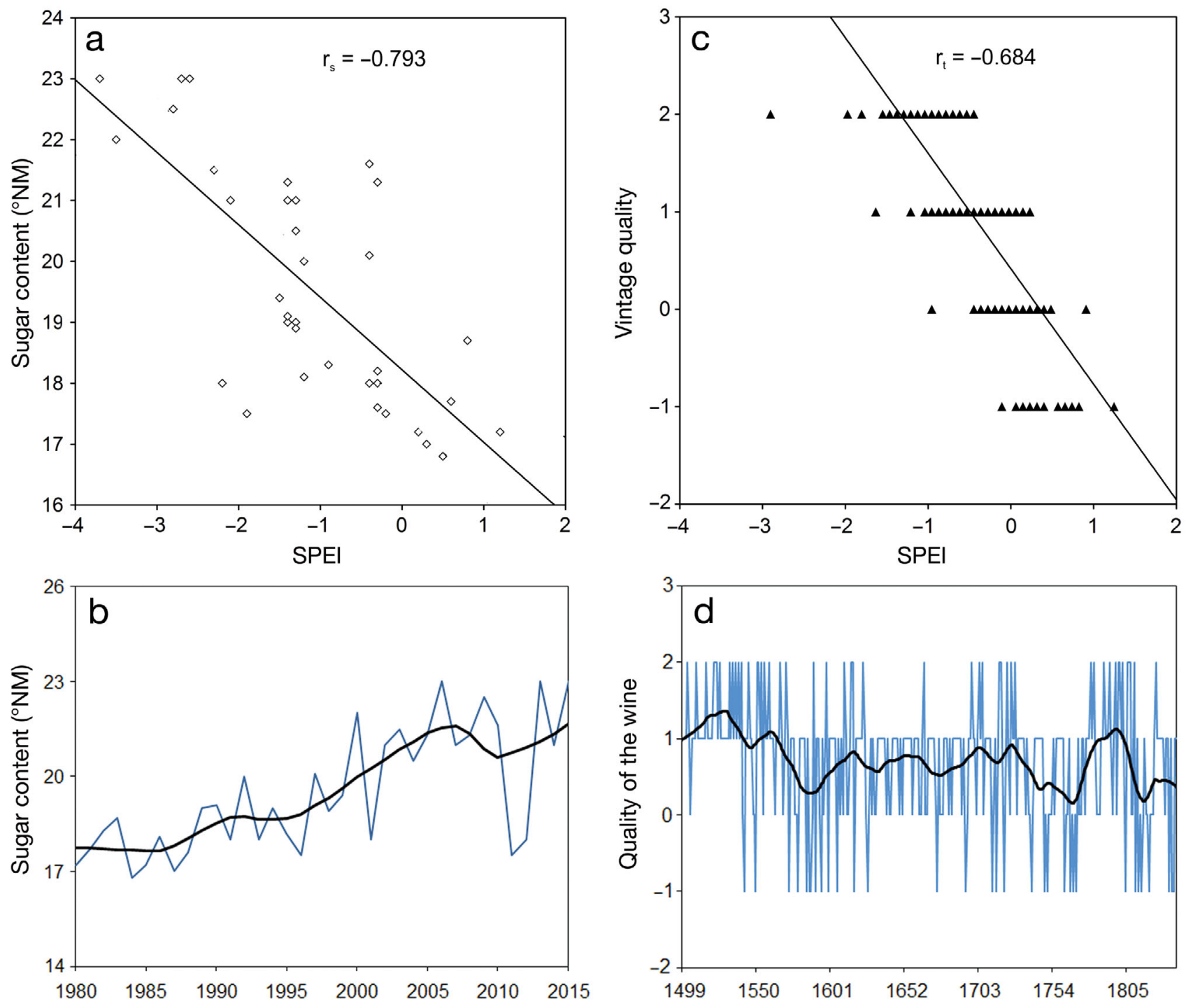

Fig. 6. Relationships between the calculated April-August SPEI values and (a) sugar content at ripeness of Vitis vinifera L. cv. Pinot Noir and (b) variation in sugar content in the Bohemian wine-growing region from 1980-2015, and (c) the relationships between reconstructed April-August SPEI values and vintage-quality (Vitis vinifera L. cv. Pinot Noir) and (d) the variation of vintage quality 1499-1840. Lines in (a) and (c) show regressions. The series in (b) and (d) are smoothed by a 10 yr Gaussian filter.

Vintage quality: 2 , excellent, 1 , good; 0 , average $;-1$, poor

between harvest timing and drought has broken down. The Palmer drought severity index (PDSI) is calculated using monthly temperature and precipitation data along with information on the waterholding capacity of soils (WMO \& GWP 2016). Brázdil et al. (2015) analyzed of long-term drought fluctuations (1805-2012) in the Czech Republic. The drying trends have been driven by a major air temperature increase, leading to higher potential evapotranspiration (and therefore to a major shift in the climatological water balance). We have not seen any change in the relationship between GDH and drought in the recent period. Our results show that it is necessary to analyze the effective precipitation, which significantly affects the water reserves in the soil. In recent years, a greater proportion of the precipitation has fallen in the form of intense one-day events, and the loss of snow cover in the winter has negatively influenced the soil water saturation in the first part of the growing season (Potopová et al. 2016). An average of $44 \%$ of the total precipitation in April-August in the Bohemian wine-growing region occurred during days with total rainfall $\geq 10 \mathrm{~mm}$ in the period from 1961 to 2000 , while in 2001-2015, this proportion was $51 \%$. Low infiltration capacity of soils and slope vineyards cause a significant proportion of the precipita- 


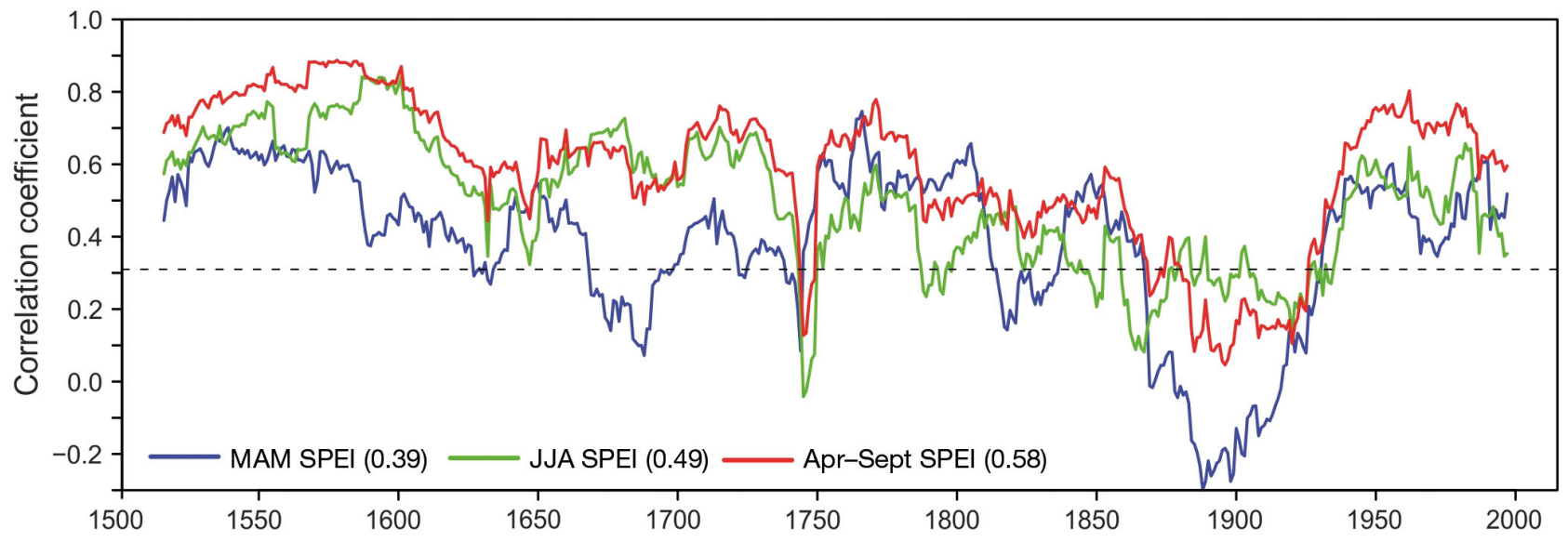

Fig. 7. Running 31 yr correlation coefficients of the GHD-based April-August SPEI of the Bohemian wine-growing region with the March-May (MAM), June-August (JJA) and April-September SPEIs of the Czech Lands derived from documentary and instrumental data (Brázdil et al. 2016a). Significant positive correlations appear above the dashed horizontal line; the overall correlation coefficients between corresponding series are indicated in parentheses

tion to be lost by surface runoff. Therefore, it is more appropriate to use the effective total precipitation than the standard total precipitation.

\subsection{Comparison of SPEI reconstructions}

The GHD-based April-August SPEI reconstruction for the Bohemian wine-growing region may be compared with the SPEI reconstructions based on documentary and instrumental data for the Czech Lands in the 1500-2015 period published by Brázdil et al. (2016a). These employed 2 series for SPEI calculations: (i) a central European temperature reconstruction (Dobrovolný et al. 2010) combining temperature indices derived from documentary data from Germany, the Czech Lands and Switzerland (1500-1854) with homogenised series from 11 central European stations (1760-2007); this series is fully representative of the territory of the Czech Lands; (ii) a precipitation reconstruction for the Czech Lands (Dobrovolný et al. 2015) combining precipitation indices derived from documentary data (1501-1854) and mean Czech areal precipitation series from instrumental measurements (1805-2015). Further, our SPEI reconstruction is compared with the March-May (MAM) SPEI, the June-August (JJA) SPEI and the AprilSeptember SPEI series for the Czech Lands compiled by Brázdil et al. (2016a) for the 1501-2012 period.

As shown in Fig. 7, the highest statistically significant correlation coefficient (0.58) was with the April-September SPEI, which differs from the highest correlation with the reconstructed GHD-based April-August SPEI by only one month (September).
The correlations with the JJA and MAM SPEI are lower (0.49 and 0.39 , respectively), which partially reflects the absence of March data in the reconstructed series as well as the stronger influence of the summer on the drought/precipitation patterns in the Czech Lands. All 3 SPEI series from Brázdil et al. (2016a) have relatively similar fluctuations with the GHD-based April-August SPEI, including a period of higher significant correlations up to the early 1850s followed by significant declines in the correlations until ca. 1925 (even negative correlations with the MAM SPEI) and then higher statistically significant correlation coefficients. The decrease in the correlation coefficients may be attributed to the some problems in the quality of the GHD series for these periods. Warmer and wetter weather in August-September in the mid-19th century led to a higher incidence of fungal diseases on hops and vines, which influenced timing (early harvest) and yields (Možný et al. in press). Effective synthetic pesticides and fungicides were not available until the early 1920s. The approach to vine growing and fermenting grapes changed in the late 19th century, affecting later harvest dates (Kilián 2012). Vine growers experimented for several years with harvesting a few days later, since sunny weather in October may have helped augment sugar content. Additional deeper declines in correlations were detected between 1650 and 1700 (only with the MAM SPEI) and in the late 1740s (all 3 SPEI series). Despite these fluctuations in the $31 \mathrm{yr}$ running correlations, this comparison of 2 independent SPEI reconstructions confirms the high reconstruction skill of documentary data (represented by grape harvest dates as well as the combi- 
nation of documentary evidence with instrumental data) to describe long-term fluctuations of droughts.

The 2 independent SPEI reconstructions from the Czech Lands indicate that 1540 was the driest year in both the 1499-2012 and 1501-2015 periods. As documented by rich documentary evidence from the Czech Lands (using only the GHD, or the combination of documentary evidence with instrumental data), 1540 was warm and dry and was associated with crop failure, lack of water, frequent fires and shortages but also with excellent wine quality (for additional details see Brázdil et al. 2013b). Similar weather characteristics and their impacts as in 1540 in the Czech Lands have been documented for many other locations in Europe, which led Wetter et al. (2014) to use the term 'megadrought' to describe an unprecedented 11 mo long drought in large parts of Europe. Although Büntgen et al. (2015) argued that 1540 does not appear to be significant in many European tree-ring width chronologies, Pfister et al. (2015) supported the original concept using other arguments. Moreover, Wetter \& Pfister (2013) classified 1540 as the warmest year based on records of grape harvest dates in Switzerland.

In addition to 1540, other important droughts in the pre-instrumental period were identified in the reconstructed GHD-based April-August SPEI for the Bohemian wine-growing region in 1590 (SPEI $=-2.1$ ) and $1616(-2.3)$; these droughts are well-documented in available documentary evidence. Comparable or higher SPEI values occurred more than 3 centuries later in $1947(-2.0)$ and particularly in the 2000s. Reconstructed SPEI values similar to that of 1540 were found for $2000(-3.4)$, which was followed by 5 other dry years in $2002(-2.5), 2003(-2.7), 2006(-2.2), 2007$ $(-2.4)$ and $2009(-2.6)$. These years have been reported and described in many studies of the area of the recent Czech Republic (e.g. Brázdil et al. 2013a,b, 2015, 2016b this Special).

All of the dry years that were identified in the reconstructed April-August SPEI values also agreed with excellent and good vintage qualities in the Bohemian wine-growing region (Pejml 1966, Možný et al. in press). Water-deficit stress resulted in shoot growth slackening, limited berry weight and enhanced berry anthocyanin content. These results are consistent with those of Brázdil et al. (2008), who found a correlation between high-quality wine and warmer and drier periods in the Moravian winegrowing region for 1800-1912. Moreover, in French Bordeaux, the intensity of regional water deficit stress was more important than the temperatures (Van Leeuwen et al. 2009).

\section{CONCLUSIONS}

GHD series have primarily been used for temperature reconstructions and have shown that prior warm weather patterns result in earlier vintage beginnings and that cooler patterns cause delayed vintage beginnings. A compilation of GHD series of Vitis vinifera L. cv. Pinot Noir for the Bohemian wine-growing region from documentary data demonstrated its potential not only for temperature reconstructions (Možný et al. 2016) but also for drought reconstructions. Statistically significant correlations of GHDs with the AprilAugust mean temperature, potential evapotranspiration and effective precipitation allowed droughts to be reconstructed using the SPEI. Standard paleoclimatological reconstruction approaches were used to obtain SPEI series for 1499-2012. The advantages of this reconstruction include the relatively long overlap period of 1841-2010 for the calibration/verification procedures and the high variance, which was stable during this period. The reconstructed series is also significantly correlated with the vintage quality; excellent and good wine quality corresponds to dry years.

The long-term April-August SPEI variations include 2 particularly important periods of high dryness: the first half of the 16th century, which included an extremely dry 1540, and the years since the late 1970s, which included a sharp increase in the dry patterns. These results demonstrate the significant influence of increasing temperatures, high total evapotranspiration and generally stable total precipitation. They also may indicate that Central Europe may be endangered by future droughts due to the continuation of global warming.

The good representativeness of the presented reconstruction is confirmed by a comparison with independent SPEI reconstructions that are based on documentary and instrumental data from the Czech Lands (Brázdil et al. 2016a). Reconstructed series that are based on GHDs can contribute to a better understanding of drought variability in Central Europe and will be used for comparisons in future studies of this topic.

Acknowledgements. We acknowledge the support of the project CzechAdapt - System for Exchange of Information on Climate Change Impacts, Vulnerability and Adaptation Measures on the Territory of the Czech Republic (EHPCZ02-OV-1-014-2014), which was supported by a grant from Iceland, Liechtenstein and Norway, and the Ministry of Education, Youth and Sports of the Czech Republic within the National Sustainability Program I (NPU I), grant number LO1415. R.B. was supported by the Grant Agency of the Czech Republic for project no. 13-19831S, and P.D. was supported by project no. 13-04291S. 


\section{LITERATURE CITED}

Allen RG, Pereira LS, Raes D, Smith M (1998) Crop evapotranspiration: guidelines for computing crop water requirements. Irrigation and drainage paper 56, FAO, Rome

Beguería S, Vicente-Serrano SM, Reig F, Latorre B (2014) Standardized precipitation evapotranspiration index (SPEI) revisited: parameter fitting, evapotranspiration models, tools, datasets and drought monitoring. Int J Climatol 34:3001-3023

Brázdil R, Pfister C, Wanner H, von Storch H, Luterbacher J (2005) Historical climatology in Europe - the state of the art. Clim Change 70:363-430

Brázdil R, Zahradníček P, Dobrovolný P, Kotyza O, Valášek $\mathrm{H}$ (2008) Historical and recent viticulture as a source of climatological knowledge in the Czech Republic. Geografie 113:351-371

Brázdil R, Trnka M, Dobrovolný P, Chromá K, Hlavinka P, Žalud Z (2009) Variability of droughts in the Czech Republic, 1881-2006. Theor Appl Climatol 97:297-315

Brázdil R, Dobrovolný P, Luterbacher J, Moberg A, Pfister C, Wheeler D, Zorita E (2010) European climate of the past 500 years: new challenges for historical climatology. Clim Change 101:7-40

Brázdil R, Bělínová $M$, Dobrovolný $\mathrm{P}$, Mikšovský J and others (2012a) Temperature and precipitation fluctuations in the Czech Lands during the instrumental period. Masaryk University, Brno

Brázdil R, Zahradníček P, Pišoft P, Štěpánek P, Bělínová M, Dobrovolný P (2012b) Temperature and precipitation fluctuations in the Czech Lands during the period of instrumental measurements. Theor Appl Climatol 110:17-34

Brázdil R, Dobrovolný P, Trnka M, Kotyza O and others (2013a) Droughts in the Czech Lands, 1090-2012 AD. Clim Past 9:1985-2002

Brázdil R, Kotyza O, Dobrovolný P, Řezníčková L, Valášek H (2013b) Climate of the sixteenth century in the Czech Lands. Masaryk University, Brno (abstract in English)

Brázdil R, Trnka M, Řezníčková L, Balek J and others (2015) Sucho v českých zemích: minulost, sou asnost, budoucnost (Drought in the Czech Lands: past, present, future). Centrum výzkumu globální změny Akademie věd České republiky, v.v.i., Brno

Brázdil R, Dobrovolný P, Trnka M, Büntgen U, Řezníčková L, Kotyza O, Valášek H (2016a) Documentary and instrumental-based drought indices for the Czech Lands back to AD 1501. Clim Res 70:103-117

> Brázdil R, Raška P, Trnka M, Zahradníček P and others (2016b) The Central European drought of 1947: causes and consequences, with particular reference to the Czech Lands. Clim Res 70:161-178

Büntgen U, Tegel W, Career M, Krusic PJ, Hayes M, Esper J (2015) Commentary to Wetter et al. (2014): Limited treering evidence for a 1540 European 'megadrought'. Clim Change 131:183-190

Burkhardt T, Hense A (1985) On the reconstruction of temperature records from proxy data in mid Europe. Arch Meteorol Geophys Bioklimatol B 35:341-359

> Chuine I, Yiou P, Viovy N, Seguin B, Daux V, Le Roy Ladurie E (2004) Historical phenology: grape ripening as a past climate indicator. Nature 432:289-290

Cook BI, Wolkovich EM (2016) Climate change decouples drought from early winegrape harvests in France. Nat
Clim Change 6:715-719

$>$ Cook ER, Briffa KR, Jones PD (1994) Spatial regression methods in dendroclimatology: a review and comparison of two techniques. Int J Climatol 14:379-402

> Daux V, Garcia de Cortazar-Atauri I, Yiou P, Chuine I and others (2012) An open-access database of grape harvest dates for climate research: data description and quality assessment. Clim Past 8:1403-1418

Dobrovolný P, Brázdil R, Valášek H, Kotyza O, Macková J, Halíčková M (2009) A standard paleoclimatological approach to temperature reconstruction in historical climatology: an example from the Czech Republic, AD 1718-2007. Int J Climatol 29:1478-1492

> Dobrovolný P, Moberg A, Brázdil R, Pfister C and others (2010) Monthly and seasonal temperature reconstructions for Central Europe derived from documentary evidence and instrumental records since AD 1500. Clim Change 101:69-107

Dobrovolný P, Brázdil R, Trnka M, Kotyza O, Valášek H (2015) Precipitation reconstruction for the Czech Lands, AD 1501-2010. Int J Climatol 35:1-14

Etien N, Daux V, Masson-Delmotte V, Stievenard M and others (2008) A bi-proxy reconstruction of Fontainebleau (France) growing season temperature from AD 1596 to 2000. Clim Past 4:91-106

García de Cortázar-Atauri I, Daux V, Garnier E, Yiou P and others (2010) Climate reconstructions from grape harvest dates: methodology and uncertainties. Holocene 20: 599-608

> Garnier E, Daux V, Yiou P, García de Cortázar-Atauri I (2011) Grapevine harvest dates in Besançon (France) between 1525 and 1847: social outcomes or climatic evidence? Clim Change 104:703-727

Glaser R, Hagedorn H (1991) The climate of Lower Franconia since 1500. Theor Appl Climatol 43:101-104

Hájková L, Voženílek V, Tolasz R, Kohut M, Možný M and others (2012) Atlas fenologických poměrů Česka (Atlas of phenological conditions in Czechia). Český hydrometeorologický ústav, Univerzita Palackého v Olomouci, Prague (abstract in English)

Hargreaves GH, Allen RG (2003) History and evaluation of Hargreaves evapotranspiration equation. J Irrig Drain Eng 129:53-63

Heim R, Brewer M (2012) The global drought monitor portal: the foundation for a global drought information system. Earth Interact 16:1-28

Hirschi M, Seneviratne SI, Alexandrov V, Boberg F and others (2011) Observational evidence for soil-moisture impact on hot extremes in southeastern Europe. Nat Geosci $4: 17-21$

> Hlavinka P, Trnka M, Balek J, Semerádová D and others (2011) Development and evaluation of the SoilClim model for water balance and soil climate estimates. Agric Water Manage 98:1249-1261

> Jones GV, White MA, Cooper OR, Storchmann K (2005) Climate change and global wine quality. Clim Change 73:319-343

Kilián J (2012) Nástin vývoje mělnického vinařství v 19. a 20. století (Outline of the development of Mělník viticulture during the 19th and 20th centuries). In: Babíková P (ed) Víno a vinařství v českých zemích po roce 1800. Regionální museum, Mělník, p 44-53

> Kiss A, Wilson R, Bariska I (2011) An experimental 392-year documentary-based multi-proxy (vine and grain) reconstruction of May-July temperatures for Köszeg, West- 
Hungary. Int J Biometeorol 55:595-611

> Le Roy Ladurie E (2005) Canicules, fraîcheurs, vendanges (France 15-19 siècles). C R Biol 328:213-222

> Le Roy Ladurie E, Baulant M (1980) Grape harvests from the fifteenth through the nineteenth centuries. J Interdiscip Hist 10:839-849

Leijonhufvud L, Wilson R, Moberg A (2008) Documentary data as proxy variables for Stockholm late winter to early spring temperatures in the 18th and 19th centuries. Holocene 18:333-343

Leijonhufvud L, Wilson R, Moberg A, Söderberg J, Retsö D, Söderlind U (2010) Five centuries of Stockholm winter/ spring temperatures reconstructed from documentary evidence and instrumental observations. Clim Change 101:109-141

Li W, Hou M, Chen H, Chen X (2012) Study on drought trend in south China based on standardized precipitation evapotranspiration index. J Nat Disasters 21:84-90

Malheiro AC, Campos R, Fraga H, Eiras-Dias J, Silvestre J, Santos JA (2013) Wine grape phenology and temperature relationships in the Lisbon wine region, Portugal. J Int Sci Vigne Vin 47:287-299

Mariani L, Parisi S, Cola FO, Zoia G, Bonardi L (2009) Tirani (1624-1930): a long time series of harvest dates for grapevine. Ital J Agrometeorol 1:7-16

> Maurer C, Koch E, Hammerl C, Hammerl T, Pokorny E (2009) BACCHUS temperature reconstruction for the period 16th to 18th centuries from Viennese and Klosterneuburg grape harvest dates. J Geophys Res 114:D22106

Meier N, Rutishauser T, Pfister C, Wanner H, Luterbacher J (2007) Grape harvest dates as a proxy for Swiss April to August temperature reconstructions back to AD 1480. Geophys Res Lett 34:L20705

Menzel A (2005) A 500 year pheno-climatological view on the 2003 heatwave in Europe assessed by grape harvest dates. Meteorol Z 14:75-77

> Miralles DG, Teuling AJ, van Heerwaarden CC, VilaGuerau de Arellano J (2014) Mega-heatwave temperatures due to combined soil desiccation and atmospheric heat accumulation. Nat Geosci 7:345-349

Mozny M, Tolasz R, Nekovar J, Sparks T, Trnka M, Zalud Z (2009) The impact of climate change on the yield and quality of Saaz hops in the Czech Republic. Agric Meteorol 149:913-919

Možný M, Brázdil R, Dobrovolný P, Trnka M (2012) Cereal harvest dates in the Czech Republic between 1501 and 2008 as a proxy for March-June temperature reconstruction. Clim Change 110:801-821

> Možný M, Brázdil R, Dobrovolný P, Trnka M (2016) AprilAugust temperatures in the Czech Lands, 1499-2012, reconstructed from grape harvest dates. Clim Past 12:1421-1435

Možný M, Hájková L, Vráblík T, Novák J, Reitschläger J, Bareš D (in press) Počasí a výnosy zemědělských plodin v České republice (Weather and crop yields in the Czech Republic). Český hydrometeorologický ústav, Prague

Paulo AA, Rosa RD, Pereira LS (2012) Climate trends and behaviour of drought indices based on precipitation and evapotranspiration in Portugal. Nat Hazards Earth Syst Sci 12:1481-1491

Pejml K (1966) Příspěvek ke kolísání klimatu v severočeské vinařské a chmelařské oblasti od r. 1500-1900 (Contribution to climate fluctuations in the North Bohemian wineand hop-growing region from 1500-1900). Český hydro- meteorologický ústav, Prague (abstract in English)

Pfister C (1981) Die Fluktuationen der Weinmosterträge im schweizerischen Weinland vom 16. bis ins frühe 19. Jahrhundert: klimatische Ursachen und sozioökonomische Bedeutung. Schweiz Z Gesch 31:445-491

Pfister C (1984) Klimageschichte der Schweiz 1525-1860, das Klima der Schweiz vom 1525-1860 und seine Bedeutung in der Geschichte von Bevölkerung und Landwirtschaft. Verlag Paul Haupt, Bern

> Pfister C, Wetter O, Brázdil R, Dobrovolný P and others (2015) Tree-rings and people-different views on the 1540 megadrought. Reply to Büntgen et al. 2015. Clim Change 131:191-198

Potop V (2011) Evolution of drought severity and its impact of corn in the Republic of Moldova. Theor Appl Climatol 105:469-483

Potop V, Možný M, Soukup J (2012) Drought at various time scales in the lowland regions and their impact on vegetable crops in the Czech Republic. Agric Meteorol 156:121-133

Potopová V, Boroneant C, Možný M, Soukup J (2016) Driving role of snow cover on soil moisture and drought development during the growing season in the Czech Republic. Int J Climatol 36:3741-3758

> Ramos MC, Jones GV, Yuste J (2015) Spatial and temporal variability of cv. Tempranillo phenology and grape quality within the Ribera del Duero DO (Spain) and relationships with climate. Int J Biometeorol 59:1849-1860

Sadras VO, Bubner R, Moran MA (2012) A large-scale, open-top system to increase temperature in realistic vineyard conditions. Agric Meteorol 154-155:187-194

Spinoni J, Naumann G, Vogt J, Barbosa P (2015) European drought climatologies and trends based on a multi-indicator approach. Global Planet Change 127:50-57

Štěpánek P (2010) ProClimDB - Software for Processing Climatological Datasets. CHMI, Brno. www.climahom.eu/ ProcData.html

Štěpánek P, Zahradníček P, Brázdil R, Tolasz R (2011) Metodologie kontroly a homogenizace časových řad $\mathrm{V}$ klimatologii (Methodology of quality control and homogenisation of time series in climatology). Český hydrometeorologický ústav, Prague (abstract in English)

Strömmer E (2003) Klima-Geschichte. Methoden der Rekonstruktion und historische Perspektive. Ostösterreich 1700 bis 1830. Franz Deuticke, Vienna

Svitáková Z, Kott I, Nekovář J (2005) Fenologická data za posledních 150 let (Phenological data in recent 150 year period). In: Bioclimatology present and future. Křtiny, 12-14 September 2005

Teuling AJ, Van Loon AF, Seneviratne SI, Lehner I and others (2013) Evapotranspiration amplifies European summer drought. Geophys Res Lett 40:2071-2075

Tolasz R, Míková T, Valeriánová A, Voženílek V (eds) (2007) Climate atlas of Czechia. Czech Hydrometeorological Institute and Palacký University, Prague

> Trnka M, Brázdil R, Možný M, Štěpánek P and others (2015) Soil moisture trends in the Czech Republic between 1961 and 2012. Int J Climatol 35:3733-3747

Urhausen S, Brienen S, Kapala A, Simmer C (2011) Climatic conditions and their impact on viticulture in the upper Moselle region. Clim Change 109:349-373

USDA Soil Conservation Service (1972) National engineering handbook, Section 4: Hydrology, Chapters 4-10, Washington, DC, 15-7-15-11

Van Leeuwen C, Tregoat O, Chone X, Bois B, Pernet D, 
Gaudillere JP (2009) Vine water status is a key factor in grape ripening and vintage quality for red bordeaux wine. How can it be assessed for vineyard management purposes? J Int Sci Vigne Vin 43:121-134

> Vicente-Serrano SM, Beguería S, López-Moreno JI (2010) A multi-scalar drought index sensitive to global warming: the standardized precipitation evapotranspiration index -SPEI. J Clim 23:1696-1718

von Storch H, Zwiers FW (1999) Statistical analysis in climate research. Cambridge University Press, Cambridge

Vršič S, Šuštar V, Pulko B, Šumenjak TK (2014) Trends in climate parameters affecting wine grape ripening in northeastern Slovenia. Clim Res 58:257-266

Webb LB, Whetton PH, Barlow EWR (2011) Observed trends in wine grape maturity in Australia. Glob Change Biol $17: 2707-2719$

Webb LB, Whetton PH, Bhend J, Darbyshire R, Briggs PR, Barlow EWR (2012) Earlier wine-grape ripening driven by climatic warming and drying and management practices. Nat Clim Change 2:259-264

Wetter O, Pfister C (2013) An underestimated record breaking event-why summer 1540 was likely warmer than 2003. Clim Past 9:41-56

Wetter O, Pfister C, Werner JP, Zorita E and others (2014) The year-long unprecedented European heat and drought of 1540 - a worst case. Clim Change 125:349-363

Whan K, Zscheischler J, Orth R, Shongwe M, Rahimi M,

Editorial responsibility: Ulf Buentgen (Guest Editor), Birmensdorf, Switzerland
Asare EO, Seneviratne SI (2015) Impact of soil moisture on extreme maximum temperatures in Europe. Weather Clim Extremes 9:57-67

> White RE (2013) Has soil drying contributed to earlier grape ripening in wine regions of southern Australia? Aust J Grape Wine Res 19:123-127

Williams J, Kannan N, Wang X, Santhi C, Arnold J (2012) Evolution of the SCS runoff curve number method and its application to continuous runoff simulation. J Hydrol Eng 17:1221-1229

WMO, GWP (World Meteorological Organization and Global Water Partnership) (2016) Handbook of drought indicators and indices (M. Svoboda and B. A. Fuchs). Integrated Drought Management Programme (IDMP), Integrated Drought Management Tools and Guidelines Series 2, Geneva

Yu M, Li G, Hayes MJ, Svoboda M, Heim RR (2014) Are droughts becoming more frequent or severe in China based on the standardized precipitation evapotranspiration index: 1951-2010? Int J Climatol 34:545-558

Zahradníček P (2009) Změna nástupu fenologických fází révy vinné a její závislost na meteorologických prvcích (The change in the phenophases onset of grapevine and its dependence on meteorological elements). In: Fyzickogeografický sborník 7, Fyzická geografie a krajinná ekologie. Masarykova univerzita, Brno, 199-205 (abstract in English)

Submitted: February 1, 2016; Accepted: August 16, 2016 Proofs received from author(s): October 19, 2016 